surface was clean and smooth, and varied in al)pearance very little from the surrounding skin.

'The time of exposure, at each sitting, was seven minutes; the surface of face was six and seveneighths inches from center of anode; the face was protected by lead mask, and the tube was a Monnell; the static machine was a ten-plate, from Otis ('lapp) \& Son.

Picture No. 1 shows the condition at first visit, Jan. 21,1901 , and before treatment.

Picture No. 2 shows condition on date of Oct. 3 , 1902 .

\section{Medical grogregz.}

\section{REPOIR'I ON I'EDIAT'RICS.}

HY THOMAS MOLUAN RO'TCH, M.1), AND JOHN LOVETI MOHSEl, M.D.

(Concluded from No. 25, ). (67!).)

TIE ILUCOCY'TOSIS OF SCARIET FEVER ANI I'TS COMPLJCATIONS. 7

Bowie, as a result of the study of the lencocytes of one hundred and sixty-seven cases of scarlet fever, draws the following conclusions:-

(1) Practically all cases of scarlatina show lencocytosis.

(2) The leucocytosis begins in the incubation period, very shortly after infection, reaches its maximum at or shortly after the height of severity of the disease, and then gradually sinks to normal.

(3) In simple, uncomplicated cases, the maximum is reached during the first week, and the normal generally some time during the first three weeks.

(4) The more severe the case, the higher the leucocytosis and the longer it lasts; the slighter the case, the slighter the lencocytosis and the shorter time it lasts.

(5) $\Lambda$ favorable case in any one variety of the disease, for example, simple, anginose, etc., has a higher leucocytosis than an unfavorable one of the same variety.

(6) The fever - that is, temperature - has no direct effect on the lencocytosis.

(7) The polymorphonuclear leucocytes are increased relatively and absolutely at first, and then fall to the normal, the lymphocytes acting inversely to this; this cycle of events occurs in simple cases within three weeks.

(8) Hosinophiles are diminished at the onset of fever. They increase rapidly in simple favorable cases until the height of the disease is past, then diminish, and finally reach the normal some time after the sum total leucocytosis has disappeared; in short, when the poison has all been eliminated.

(9) The more severe the case, the longer are the eosinophiles subnormal before they rise again, as described above (vide 8 ) ; in fatal cases they never rise, but sink rapidly toward zero and remain there.

(10) The lencocytes, in complications, go through a cycle of events similar in all respects to that of the primary fever, as regards sum total and differential lencocytosis, and the same laws govern the behavior of the leucocytes in both cases.

Bowle ('l'he Jourmal of l'athology and Bacterlology, March, 1s(re, vol. vili, No. 1, J. 82). Alistruct In Amerlcan Journal of the Medical sciences, lioe, vol. cxxiv, p. 168 . lowie thinks that the eosinophilia and its persistence for a consicierable time is of value in diagnos ing the disease from tonsilitis and septic conditions, with both of which the clisease is likely to be mistaken. He also believes that the course of the eosinophiles is of value from a prognostic standpoint. If they are normal or subnormal after the first day or two, then the case will in all probability be a severe one. $\Lambda$ s long as a relative increase of eosinophiles is present, we cannot be sure that some complication will not ensue; while, if the eosinophiles have come down to normal in the usual way, we should be free from anxiety in this respect.

A STUDY OF HYPERPLASIA OF THE PHARYNGEAI.

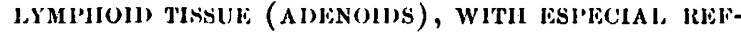
BRENCE TO PRIMARY TUBBRCULOSIS OF 'THE PIIARYNGEAL TONSIL. ${ }^{8}$

They tested seventy-five consecutive specimens of adenoids for tuberculosis. Inoculation experiments and histological examinations were made in each case. 'The animal experiments were very carefully performed. 'I'ubercle bacilli were looked for only in those specimens which induced tuberenlosis in the guinea pigs, as the authors assumed that the inoculation test was far more delicate than the search for tubercle bacilli. (of the seventy-five specimens tested, twelve induced tuberculosis in the inoculated animals. 'Tubercle bacilli and lesions characteristic of tuberculosis were found in the tissues of eiglit. 'The l'emaining four contained tubercle bacilli, but showed no histological lesions of tubereulosis. In all cases the bacilli were more or less close to the surface and few in number. In seven cases the lesions were situated peripherally. In only one was there a lesion in the micldle of the adenoid tissue. 'They are inclined to include the cases presenting bacilli, but find no characteristic lesions anong the tubejcular cases. Their work is the nost complete which has yet been done. 'They point out that most careful work is necessary to determine the frequency of tubereulosis of alenoid tissue.

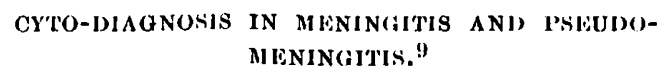

From the study of cases and of the literature he arrives at the following conclusions :-

(1) In tubercular meningitis there is almost always lymphocytosis, exceptionally polynucleosis.

(2) In cerebrospinal meningitis there is almost always polynucleosis, exceptionally lymphocytosis.

(3) Sometimes the cyto-cliagnosis is misleading. It may be negative in cases of meningitis or it may be positive in cases in which there is no meningitis. The lencocytic reaction shows quantitative variations which follow the intensity and course of the disease. It diminishes and disaypears with recovery.

The lencocytic reaction is variable in the meningeal complications of typhoid fever. The presence of a lymphocytosis in this disease does not necessarily mean a complicating tubereular meningitis.

There are no definite data as to the cyto-diagnosis of psendomeningitis.

" $\Lambda$ incricun Journal of the Melicnl Sclences, June, 1902, Dr. $\Lambda . J$. Lartlgau and Ir. Matihlas Nicoll, Jr.

"Demange: 'T'hèse to P'aris, 1902. Reviow in Revio Alensuollo des Maludies do l'jinfance, vol. $x x, p .421$. 


\section{TIHE RLLATION OF TIIE THYMUS GLAND TO MARASMUS. ${ }^{10}$}

They consider that marasmus, or infantile atrophy, is not due to the amount of food ingrested nor to the amount absorbed from the intestinal tract, lut to malassimilation of the food material in the hody. 'Trustworthy observations show that the size and condition of the thymus gland is an index to the state of the nutrition of the body. The normal weight of the thymus in infancy is about eighteen grams.

They stuclied the pathological changes in the thymus gland in eighteen cases of infantile atropliy. 'The lowest weight of the thymus was 1.2 grams (three cases) and the highest 7.5 grams. The average weight in sixteen cases was only 2.2 grams. In all these cases the other organs were carefully studied. No abnormal changes were found except occisional acute congestions from inflammation of the lungrs, due to terminal infections.

The microseopical examination of the atrophied glands sloowed conditions differing widely from normal and also from those found in normal involution. 'The fibrous capsule was thicker than norinal, the trabecula were greatly thickened, and the lobules were frequently cut up into irregular masses by the increased interlobular tissue. 'The inclease of comncetive tissue was of ten very apparent about the blood vessels, even surrounding the dilated capillaries. In some cases the fibrous tissue was more abundant than the lymphoid structure. 'The reticular tissue was increased and the endothelial cells lining the reticular spaces were more numerous. Consequently, leucocytes and other similar elements present in these spaces were decreased in number and the lymphoid structure of the gland of ten greatly altered.

They also sturlied the pathological changes in the thymus gland in two cases of tuberculosis of the lungs with general acute miliary tubereulosis, and in one case of tuberculous meningitis. 'These glands showed increased fibrosis and hyaline degeneration and swelling of the Hassall bodies. They found that the differences between the chinges in the gland of infantile atrophy and those of secondary atrophy were only in clegree.

They consider that the state of nutrition of infantis may be estimated by a microscopical examination of the thymus, and that the weight of the thymus gland is the best index of the nutrition of the body.

'They gave twelve infants who were under only fair lyggienic and dictetic conditions from two to three grains of the dried gland three times daily for a month. As the children were not weighed, the results can only be estimated. Two of the infants died; the others showed no appreciable change. Four other cases had admirable surroundings, food and nursing. 'They did not gain under the hest of eonditions. 'The first ense died in three days, the second, in two and a half weeks and the thirr in two months. 'The fourth gained stealily and was discharged cured.

"Stoken, Ruhrah mus Rohrer. Amerlenn Jourmal of the Meilieal Selences, lyo:, vol. exxiv, p. siti.

\section{Itepartw of Socictica.}

\section{SIFFOIK DIS'RRIC'P MEDICAI, SOCIETY.}

FRGDERIC.J. CO'TTON, M.D., SECKETARY.

STATED meeting Saturday, Oct. 25, 19(02, 1)1. Tuomas Morgan Rotch presiding. Dri. Willatam S. 'Thayiz of Baltimore read a paper entitled

REMARKS ON THE TEACHING OF PITSICAL DIATNONIS.'

'The Presinen't: We are very much indebted to lrofessor 'Thayer for his exceedingly valuable exposition of this subject, which is of so much interest to you all. I will ask Dr. Henry dackson to open the cliscussion.

Dr. Henry Jackson: We have listened with great pleasure to Dr. 'Thayer's remarks on his long experience in teaching physical diagnosis. I recognize with a certain degree of local pricle that certain of the principles which he has elucidated and elaborated had their origin in our common school. I was much interested to see that he opened his remarks with an earnest appeal for instruction in anatomy in the normal individual, a study of the organs in normal conditions, for as we see students in the hospital we are much surprised and of ten chagrined to find that their knowledge of the normal conditions of the body is of ten deficient. If they ex:mined with more care the normal individual we would lind fewer dingnoses of ablominal aneurism, to mention a single instance. Also, it is of much interest to hear what he said of dispensary eases. It is a great temptation to show students rare and interesting cases which come into our warls, cases that have taxed our knowledge, eases we have studied with great care, in which, by some new method of physical diagnosis, we have been able to arrive at a correct diagnosis, or think we have. Those cases they will rarely sec. An important matter in the instruction is to show simple average cases they will meet eonstantly in their practice. In the last few years it has been a cause of a good deal of chagrin on my part to find that the men when they arrive at. the upper elasses are more thoromohly versed in the modern and recondite methods of investigation of disease than in the more simple methods which have been studied for years. One point in physical diagnosis is, l think, of great importance, and one l feel that the student grasps at the very last. livery one knows whether a personal friend looks ill or well, but it seems to me that that is the last point which strikes the student in the examination of the patient. They do not ralize whether the patient is an extremely ill individual or in fairly good condition.

I can add another story to 1)r. 'Thayer's description of the student who did not recognize pnenmonia. One of my confrires was called to a walld by a nurse to see a very sick patient; he examined the patient with great care, and said he had not the wildest idea what was the matler. Just as he was going out, she saicl, "Doctor, what treatment shall I give the pneumonia?"

D). H. 1). $\Lambda$ kN(1,1): I might emphasize one or two of the points that have impressed me in the work of teaching medical stulents. One thing i sec page tisa of the Jourmal. 